\title{
Pediatric Metastatic Crohn's Disease
}

\section{Doença de Crohn metastática pediátrica}

\author{
Amanda Trindade de Oliveira ${ }^{10}$ Raissa Albuquerque Calais de Oliveira ${ }^{2}$ \\ Matheus Matta Machado Duque Estrada Meyer ${ }^{30}$ Ilson Geraldo da Silva ${ }^{3}$ Matheus Duarte Massahud ${ }^{3(0)}$ \\ ${ }^{1}$ Instituto Fernandes Figueira, Rio de Janeiro, RJ, Brazil \\ 2 Hosital Arnaldo Gavazza Filho, Pte. Nova, MG, Brazil \\ ${ }^{3}$ Santa Casa de Misericórdia de Belo Horizonte, Belo Horizonte, MG, Brazil \\ Address for correspondence Matheus Duarte Massahud, MD, \\ Coloproctologista, Santa Casa de Misericórdia de Belo Horizonte, Belo \\ Horizonte, MG, Brazil (e-mail: matheusduarte@gmail.com).
}

J Coloproctol 2021;41(1):79-82.

\begin{abstract}
Keywords

- Crohn's disease

- pediatric

- metastatic

- extraintestinal

- manifestations
\end{abstract}

\section{Resumo}

received

April 30, 2020

accepted

June 7,2020
Crohn's disease $(C D)$ is a chronic, relapsing, idiopathic condition, characterized by granulomatous, transmural inflammation of the gastrointestinal tract, which can affect its entire length, from mouth to anus. Metastatic Crohn's disease (MCD) is a rare form of skin involvement and is defined by skin lesions without contiguity with the gastrointestinal tract. A 9-year-old patient presented with gastrointestinal complaints and gross skin lesions in the vulva and perianal region. The diagnosis of Crohn's disease was made when the patient was 11 years old, after being evaluated by the colorectal surgeon. Treatment was started with a "top-down" approach, with a sustained response for four years. Afterwards, there was a relapse of the skin disease in previously normal areas, without overt symptoms. Treatment consisted of steroids and local infiltration of infliximab, without improvement. A year later, there was a rapid progression of the skin lesions, and the drug changed to adalimumab, also without response and worsening of the skin lesions. The patient was admitted to the hospital and intravenous steroids were initiated, along with surgical debridement of the lesions. After some improvement, ustekinumab was initiated with satisfactory response. Pediatric MCD has an important impact on the patient's quality of life, with influences on growth and social development.

A doença de Crohn é uma condição idiopática crônica, recidivante, caracterizada por inflamação granulomatosa transmural do trato gastrointestinal, que pode afetar toda a sua extensão, da boca ao ânus. A doença de Crohn metastática (DCM) é uma forma rara que envolve a pele, e é definida por lesões cutâneas sem contiguidade com o trato gastrointestinal. Uma paciente de 9 anos de idade apresentou queixas gastrointestinais e lesões cutâneas grosseiras na vulva e na região perianal. O diagnóstico de doença de Crohn foi feito quando a paciente tinha 11 anos, após avaliação do coloproctologista. $\mathrm{O}$ tratamento foi então iniciado com uma abordagem "top-down", com uma resposta mantida por quatro anos. Posteriormente, houve recidiva da doença de pele em áreas 
Palavras-chave

- doença de Crohn

- pediátrica

- metastática

- manifestações

- extraintestinais anteriormente normais, sem sintomas evidentes. O tratamento consistiu em corticoide e infiltração local de infliximabe, sem melhora. Um ano depois, houve rápida progressão das lesões cutâneas, sendo a medicação alterada para adalimumabe, também sem resposta e com piora das lesões cutâneas. A paciente foi internada e iniciado tratamento com corticoide intravenoso, juntamente com o desbridamento cirúrgico das lesões. Após alguma melhora, o ustecinumabe foi iniciado com resposta satisfatória. A DCM pediátrica tem um impacto importante na qualidade de vida do paciente, com influências no crescimento e no desenvolvimento social.

\section{Introduction}

Crohn's disease (CD) is a chronic, relapsing, idiopathic condition, characterized by granulomatous, transmural inflammation of the gastrointestinal tract, which can affect its entire length, from mouth to anus. ${ }^{1}$ The disease results from an interaction between genetic, immune, and environmental factors, ${ }^{2}$ and, although it is more prevalent in adults, its pediatric incidence is rising. Extraintestinal manifestations can appear at the time of diagnosis, before, or after. ${ }^{3}$ Metastatic Chron disease (MCD) is a rare form of skin involvement without contiguity with the gastrointestinal tract. $^{3,4}$ The extraintestinal findings can be present without important abdominal symptoms, making MCD a challenge.

\section{Methods}

Review of medical records, exam results and pathology reports. Literature review was performed on the PubMed database, using the following terms: Crohn's disease, cutaneous manifestations, pediatric, and metastatic. Each of the terms was combined with the others accepted for search.

\section{Case Report}

The present case report is that of an 18-year-old female patient. At age 9 , she started with unspecific change in bowel habits, associated with abdominal pain. Then, she evolved with gross skin manifestations in the vulvar and perianal areas, including ulcerations, fistula tracts, and abscesses. There was difficulty in obtaining a diagnosis at the time, with primary care physicians. At 11 years old, she was sent to a tertiary center for a consultation with a coloproctologist, who made the diagnosis of MCD. Colonoscopy identified small mucosal ulcers, and the pathology report showed a nonspecific ileitis, skin lesions biopsies revealed lymphohistiocytic deep and superficial dermatitis associated with perifolliculitis, with small granulomas and focal necrosis. She was submitted to seton drainage and a "top down" approach initiated with azathioprine and infliximab. There was a good sustained clinical response for 4 years, with the need, however, to increase infliximab's dosage. At 15, there was a disease relapse in previously normal areas: breasts and armpits, with abscesses and purulent drainage, although the symptoms were not intense. It was then tried, without success, steroid therapy plus local infliximab. On the follow- ing year, she presented with rapid progression of the skin lesions, and biologic therapy was modified to adalimumab. There was no response, but a significant worsening of the skin diseases with purulent drainage in the armpits, inframammary area, groin, and suprapubic areas (-Fig. 1) associated with ulcerated lesions on the lower limbs and inferior abdomen. She was admitted to the hospital, and intravenous steroids, optimized pain management, and surgical debridement of the lesions were started immediately (-Figs. 2 and 3). Finally, adalimumab was changed to ustekinumab, with the treatment starting on January 2019. After 8 weeks, we noted a significant healing of the skin lesions. However, she quickly presented with another relapse of the skin lesions, especially on the left breast, with significant purulent drainage. A simple mastectomy was performed with a good postoperative outcome. Presently, the patient is being followed by the coloproctology and plastic surgery staff at our institution (-Fig. 4).

\section{Discussion}

Metastatic Crohn's disease presents with a difficult diagnosis, as its findings can precede gastrointestinal manifestations or

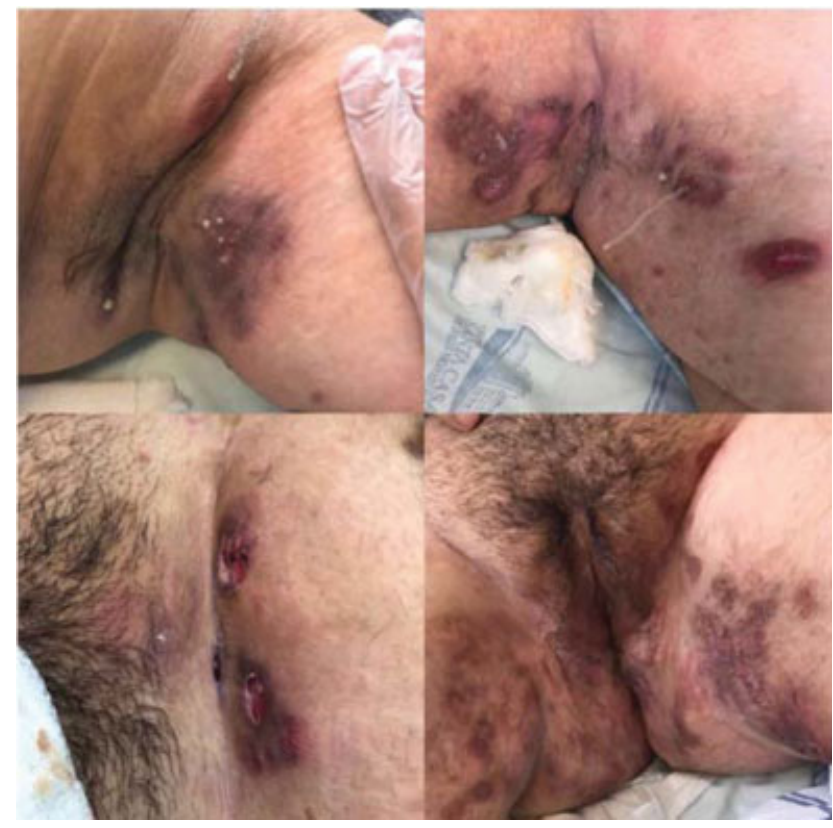

Fig. 1 Left armpit, right armpit, suprapubic, perineum/vulva. 


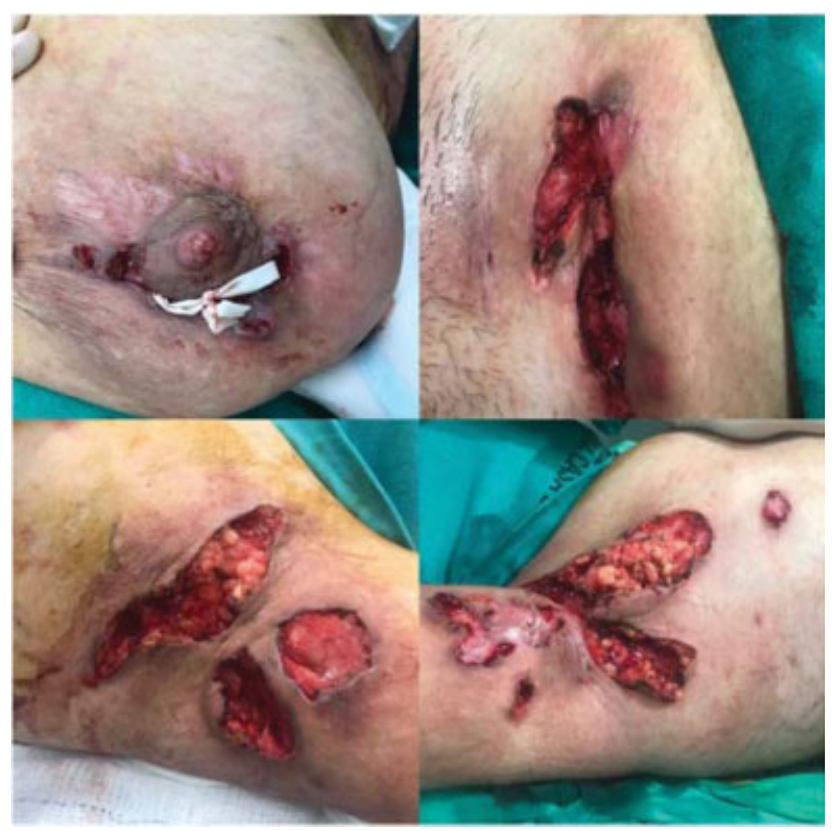

Fig. 2 Intraoperatory - breast, suprapubic, left armpit, right armpit.

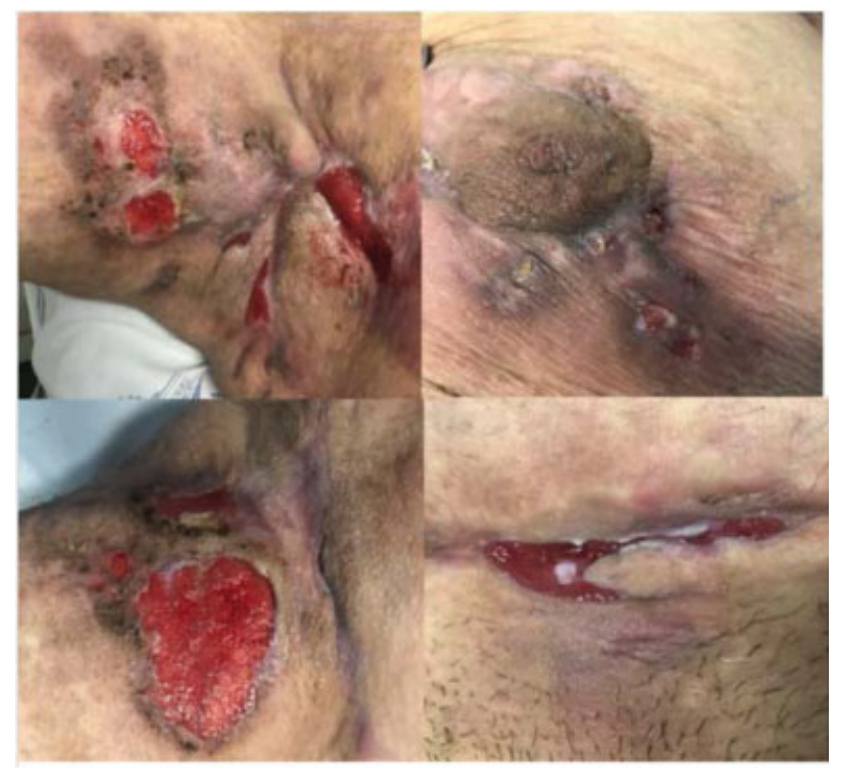

occur with unspecific gastrointestinal symptoms. ${ }^{5,6}$ It is a rare extraintestinal manifestation, without a well-defined physiopathology and also without a standard treatment regimen. ${ }^{7}$ In the present case, we need to address an important differential diagnosis: hidradenitis suppurativa (HS). Hidradenitis suppurativa can present in a similar fashion, and we know it is associated with $\mathrm{CD}^{8}$ Hidradenitis suppurativa also has its highest incidence among teenagers and female patients, such as the patient described above. ${ }^{9}$ Both $\mathrm{CD}$ and HS have similar immunological mechanisms, which can explain a successful treatment with ustekinumab in some settings. ${ }^{10}$ The clinical treatment for $C D$ has as its main objectives: relief of symptoms, mucosal healing, intestinal function preservation, prolonged remission, improvement of quality of life, prevention and treatment of complications. Immunomodulators are the cornerstone of long-term treatment, mostly in individuals who are steroid-dependent. Steroids act as immunosuppressors, being useful in acute flares; however, they are not suitable for maintenance treatment because of the side effects. Biologics are drugs with potential to induce remission in moderate-to-severe disease and can be used as maintenance treatment in those patients. The most studied are the antitumor necrosis factor (anti-TNF)- $\alpha$ : infliximab and adalimumab. According to the a randomized, multicenter, open-label study to evaluate the safety and efficacy of anti-TNFa chimeric monoclonal antibody (infliximab, REMICADEC) in pediatric subjects with moderate-to-severe Crohn's disease (REACH) study, $64 \%$ of patients on maintenance therapy with infliximab present clinical response, and 56\% present remission. This was superior to adalimumab, which presented $33.5 \%$ of remission, according to the IMAgINE study. ${ }^{11,12}$ Surgical treatment is reserved for treatment of complications and clinical treatment failure. ${ }^{13}$ Due to the lack of treatment response and early relapse after surgical debridement, ustekinumab therapy was started. Ustekinumab is a biologic that has the interleukins (ILs) 12 and 23 as its targets. It is an effective drug in CD patients that fail therapy with anti-TNF $\alpha^{14}$ and there are case reports of its effectiveness on MCD, although it is necessary to use higher doses than in the treatment of intestinal disease.

Fig. 3 Postoperatory - right armpit, breast, left armpit, suprapubic.

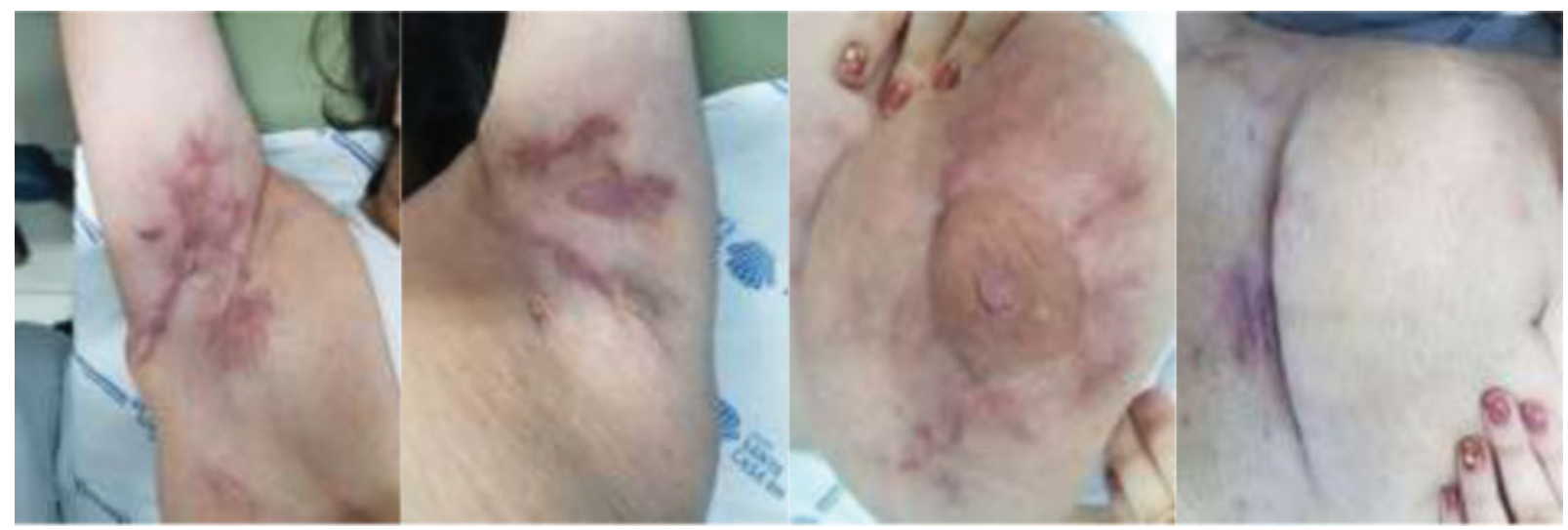

Fig. 4 After 4 weeks of ustekinumab - right armpit, left armpit, breast, suprapubic. 


\section{Conclusion}

Metastatic Crohn's disease is a rare and uncomprehend extraintestinal manifestation of $\mathrm{CD}$. Its occurrence in the pediatric population has a huge impact on the quality of life, influencing growth, sexual, and emotional development. ${ }^{15}$ Metastatic Crohn's disease has a low incidence, but it is important to have in mind that it can precede the diagnosis of CD in 50 to $86 \%$ of pediatric cases. ${ }^{1}$ Since it is a rare manifestation with a difficult diagnosis, there is a delay in appropriate treatment, thus delaying adequate control of the symptoms and skin lesions. ${ }^{16}$

\section{Note}

The objective of the present paper is to address a case of metastatic $C D$, a rare manifestation of Crohn's in a pediatric patient.

We reviewed the medical records, from the patient's first consultation, with our group. We also did a literature review, searching for publications regarding MCD and CD in the pediatric population.

\section{Conflict of Interests}

The authors declare that there is no conflict of interests.

\section{References}

1 Sabbadini C, Banzato C, Schena D, Peroni D, Girolomoni G. Metastatic Crohn's disease in childhood. J Dtsch Dermatol Ges 2016;14(04):431-434

2 Gomollón F, Dignass A, Annese V, et al. 3rd European Evidencebased Consensus on the Diagnosis and Management of Crohn's Disease 2016: Part 1: Diagnosis and Medical Management. J Crohn's Colitis 2017;11(01):3-25

3 Blasco Alonso J, Girón Fernández-Crehuet F, Lendínez Ramírez MA, et al. Metastatic Crohn's disease in pediatrics. Rev Esp Enferm Dig 2016;108(09):598-603
4 Ahad T, Riley A, Martindale E, von Bremen B, Owen C. Vulvar swelling as the first presentation of Crohn's disease in children-A report of three cases. Pediatr Dermatol 2018;35(01):e1-e4

5 Freeman HJ. Natural history and long-term clinical course of Crohn's disease. World J Gastroenterol 2014;20(01):31-36

6 Papacosta NG, Nunes GM, Pacheco RJ, Cardoso MJ, Guedes VR. Doença de Crohn: um artigo de revisão. Revista de Patologia do Tocantins 2017;4(02):25-35

7 Kurtzman DJB, Jones T, Lian F, Peng LS. Metastatic Crohn's disease: a review and approach to therapy. J Am Acad Dermatol 2014;71 (04):804-813

8 Church JM, Fazio VW, Lavery IC, Oakley JR, Milsom JW. The differential diagnosis and comorbidity of hidradenitis suppurativa and perianal Crohn's disease. Int J Colorectal Dis 1993;8(03):117-119

9 Giudici F, Maggi L, Santi R, et al. Perianal Crohn's disease and hidradenitis suppurativa: a possible common immunological scenario. Clin Mol Allergy 2015;13(01):12

10 Chen WT, Chi CC. Association of hidradenitis suppurativa with inflammatory bowel disease. A systematic review and metaanalysis. JAMA Dermatol 2019;155(09):1022-1027

11 Hyams JS, Griffiths A, Markowitz J, et al. Safety and efficacy of adalimumab for moderate to severe Crohn's disease in children. Gastroenterology 2012;143(02):365-74.e2

12 Campos TA, Águeda S, Rebelo J, et al. Modificação do tratamento com infliximab na doença de Crohn: experiência de um centro. Jornal Português de Gastroenterologia 2014;21(02):55-59

13 Sigall Boneh R, Sarbagili Shabat C, Yanai H, et al. Dietary therapy with the Crohn's disease exclusion diet is a successful strategy for induction of remission in children and adults failing biological therapy. J Crohn's Colitis 2017;11(10):1205-1212

14 Abdat R, Markova A, Farraye FA, Lichtman MK. Ustekinumab for treatment of cutaneous Crohn's disease. Dermatol Online J 2016; 22(10):13030/qt6v402170

15 Ruemmele FM, Veres G, Kolho KL, et al; European Crohn's and Colitis Organisation European Society of Pediatric Gastroenterology, Hepatology and Nutrition. Consensus guidelines of ECCO/ESPGHAN on the medical management of pediatric Crohn's disease. J Crohn's Colitis 2014;8(10):1179-1207

16 Warsi QA, Kunduru M, Karjoo M, Beg M. Genital involvement in pre-pubertal pediatric population: a rare aspect of Crohn's disease. Int J Pediatr 2016;4(09):3399-3404 